\title{
Svornostite, $\mathrm{K}_{2} \mathrm{Mg}\left[\left(\mathrm{UO}_{2}\right)\left(\mathrm{SO}_{4}\right)_{2}\right] \cdot 8 \mathrm{H}_{2} \mathrm{O}$, a new uranyl sulfate mineral from Jáchymov, Czech Republic
}

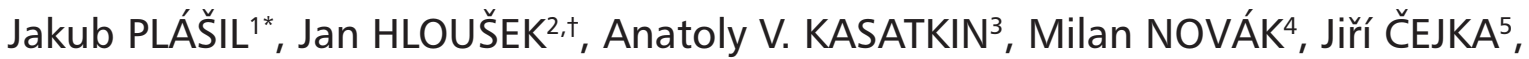 \\ Ladislav LAPČÁK ${ }^{6}$
}

${ }^{1}$ Institute of Physics, Academy of Sciences of the Czech Republic v.v.i., Na Slovance 2, 18221 Prague 8, Czech Republic; plasil@fzu.cz

${ }^{2}$ U Roháčových kasáren 24, 10000 Prague 10, Czech Republic

${ }^{3}$ Fersman Mineralogical Museum of the Russian Academy of Sciences, Leninsky Prospekt 18-2, 119071 Moscow, Russia

${ }^{4}$ Department of Geological Sciences, Masaryk University, Kotlářská 2, 61137 Brno, Czech Republic

${ }^{5}$ Department of Mineralogy and Petrology, National Museum, Cirkusová 1740, 19300 Prague 9, Czech Republic

${ }^{6}$ Institute of Chemical Technology, Prague, Technická 5, 16628 Prague 6, Czech Republic

+ deceased on April 27, 2014

* Corresponding author

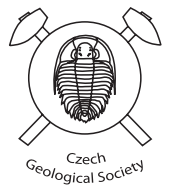

Svornostite (IMA2014-078), $\mathrm{K}_{2} \mathrm{Mg}\left[\left(\mathrm{UO}_{2}\right)\left(\mathrm{SO}_{4}\right)_{2}\right]_{2} \cdot 8 \mathrm{H}_{2} \mathrm{O}$, is a new uranyl sulfate mineral from Jáchymov, Western Bohemia, Czech Republic. The new mineral was found in material originating from the Geschieber vein in the Svornost mine. It occurs as crystalline crusts composed of yellow prismatic crystals on a gangue along with geschieberite, adolfpateraite and gypsum. It is a low-temperature, supergene mineral formed by the post-mining weathering of uraninite. Svornostite is orthorhombic, the space group $P m n{ }_{1}$, with the unit-cell parameters $a=12.7850(3), b=8.2683(4), c=11.2163(3) \AA$, $V=1185.68(7) \AA^{3}$ and $Z=2$. Crystals are long prisms elongated on [001] and flattened on $\{100\}$. Crystals exhibit the forms $\{100\},\{010\}$ and $\{011\}$, usually forming multiple intergrowths. Svornostite is light yellow and has a very pale yellow streak. It exhibits a strong yellowish-green fluorescence under both long-wave and short-wave UV. It is translucent to transparent with strong vitreous luster. The mineral has a Mohs hardness $\sim 2$; it is brittle, with uneven fracture and a perfect cleavage, on $\{100\}$ and $\{010\}$. The calculated density based on the empirical formula is $3.268 \mathrm{~g} / \mathrm{cm}^{3}$. The mineral is optically biaxial (+), with $\alpha=1.548(2), \beta=1.556(3)$ and $\gamma=1.585(2)$ (measured at $590 \mathrm{~nm}$ ). The $2 \mathrm{~V}$ was not measured, calculated value is $56^{\circ}$. Birefringence is 0.037 . No dispersion or pleochroism was observed. The optical orientation is $Z=$ c. Chemical analysis (EDS, 6 spots) is $\mathrm{K}_{2} \mathrm{O} 7.93, \mathrm{MgO} 3.11, \mathrm{CuO} 0.79, \mathrm{SO}_{3} 28.13, \mathrm{UO}_{3} 48.94, \mathrm{H}_{2} \mathrm{O}$ (calc.) 12.53, total 101.43 wt. \%, which yields the empirical formula $\mathrm{K}_{1.94}\left(\mathrm{Mg}_{0.89} \mathrm{Cu}_{0.11}\right)_{\Sigma 1.00}\left(\mathrm{U}_{0.99} \mathrm{O}_{2}\right)_{2}\left(\mathrm{~S}_{1.01} \mathrm{O}_{4}\right)_{4}\left(\mathrm{H}_{2} \mathrm{O}\right)_{8}($ based on $28 \mathrm{O} a p f u)$. Prominent features in the Raman spectrum include the $\mathrm{O}-\mathrm{H}$ stretching vibrations, symmetric stretching vibrations of $\left(\mathrm{UO}_{2}\right)^{2+}$ ion, and stretching and bending vibrations of symmetrically non-equivalent $\mathrm{SO}_{4}$ groups. The eight strongest powder X-ray diffraction lines are $\left[d_{\text {obs }} \AA\left(I_{\text {rel }}\right)(h k l)\right]: 8.279(50)(010), 6.398(100)(200), 5.060(55)(210), 4.645(40)(012)$, $4.610(38)(211), 3.881(34)(021), 3.318(44)(221), 3.009(44)(213)$. The crystal structure of svornostite $(R=0.023$ for 2745 reflections with $\left.I_{\text {obs }}>3 \sigma[I]\right)$ contains infinite uranyl sulfate chains of composition $\left[\left(\mathrm{UO}_{2}\right)\left(\mathrm{SO}_{4}\right)_{2}\left(\mathrm{H}_{2} \mathrm{O}\right)\right]^{2-}$ parallel to $(001)$. The adjacent chains are linked through the $\mathrm{Mg}^{2+}$-octahedra linked to the apical $\mathrm{O}$ atoms of the $\mathrm{SO}_{4}$ groups with the chains and additionally by the $\mathrm{K}-\mathrm{O}$ bonds and also $\mathrm{H}$-bonds involving $\mathrm{H}_{2} \mathrm{O}$ molecules. The uranyl sulfate chains are the same as found in the structures of several others uranyl sulfate minerals.

Keywords: svornostite, new mineral, uranyl sulfate, crystal structure, bond-valence, Jáchymov

Received: 10 February 2015; accepted: 24 March 2015; handling editor: F. Laufek

The online version of this article (doi: 10.3190/jgeosci.192) contains supplementary electronic material.

\section{Introduction}

Uranyl sulfates typically occur as supergene alteration products after hydration-oxidation weathering of uraninite (Plášil 2014). They are relatively common since uraninite is often associated with sulfides such as pyrite, marcasite or chalcopyrite (Finch and Murakami 1999; Krivovichev and Plášil 2013). Uranyl sulfates usually form during oxidizing weathering of sulfides and $U$ ores in the old mining workings by the process connected to the acid mine drainage (AMD) (Fernandes et al. 1995;
Brugger et al. 2003; Johnson 2003; Johnson and Hallberg 2005), generating highly mobile acid solutions containing dissolved $\mathrm{UO}_{2}^{2+}$.

Svornostite is further new uranyl sulfate mineral found in Jáchymov (Joachimsthal), Czech Republic. The new mineral and the name were approved by the Commission for the new Minerals, Names and Classification of International Mineralogical Association (IMA2014-078). The new mineral was named after the type locality, abandoned Svornost mine (also known as Einigkeit in German). The holotype specimen is deposited in the collections of the 
Fersman Mineralogical Museum of the Russian Academy of Sciences, Moscow, Russia, registration number 4537/1.

\section{Occurrence}

Svornostite was found on a single specimen collected from Geschieber vein on the $5^{\text {th }}$ level of the Svornost mine, Jáchymov, Western Bohemia, Czech Republic by one of the authors $(\mathrm{JH})$. The description of the locality and its geological setting has been already given in detail elsewhere (e.g., Ondruš et al. 1997, 2003; Tvrdý and Plášil 2010; Hloušek et al. 2014). The Jáchymov ore district is a classic example of the Variscan hydrothermal vein type of deposit, so-called five-elements formation, Ag-Bi-Co-Ni-(U). Jáchymov is the type locality for 43 minerals and more than 430 minerals have been identified from there.

Minerals found in direct spatial association with svornostite include geschieberite, $\mathrm{K}_{2}\left(\mathrm{UO}_{2}\right)\left(\mathrm{SO}_{4}\right)_{2} \cdot 2 \mathrm{H}_{2} \mathrm{O}$ (IMA2014-006; Plášil et al. 2014a) and adolfpateraite (Plášil et al. 2012). Minerals are of supergene origin and formed during alteration during post-mining processes.

\section{Physical and optical properties}

Svornostite forms markedly elongated prisms (Fig. 1) in multiple intergrowths. Crystals, up to $0.2 \mathrm{~mm}$ across, are flattened on $\{100\}$ and elongated parallel to [001]. It is light yellow in crystals and bright yellow in larger aggregates with a very pale yellow streak. Crystals are transparent to translucent (if thicker) with a vitreous luster. They are brittle, with a perfect cleavage on $\{100\}$

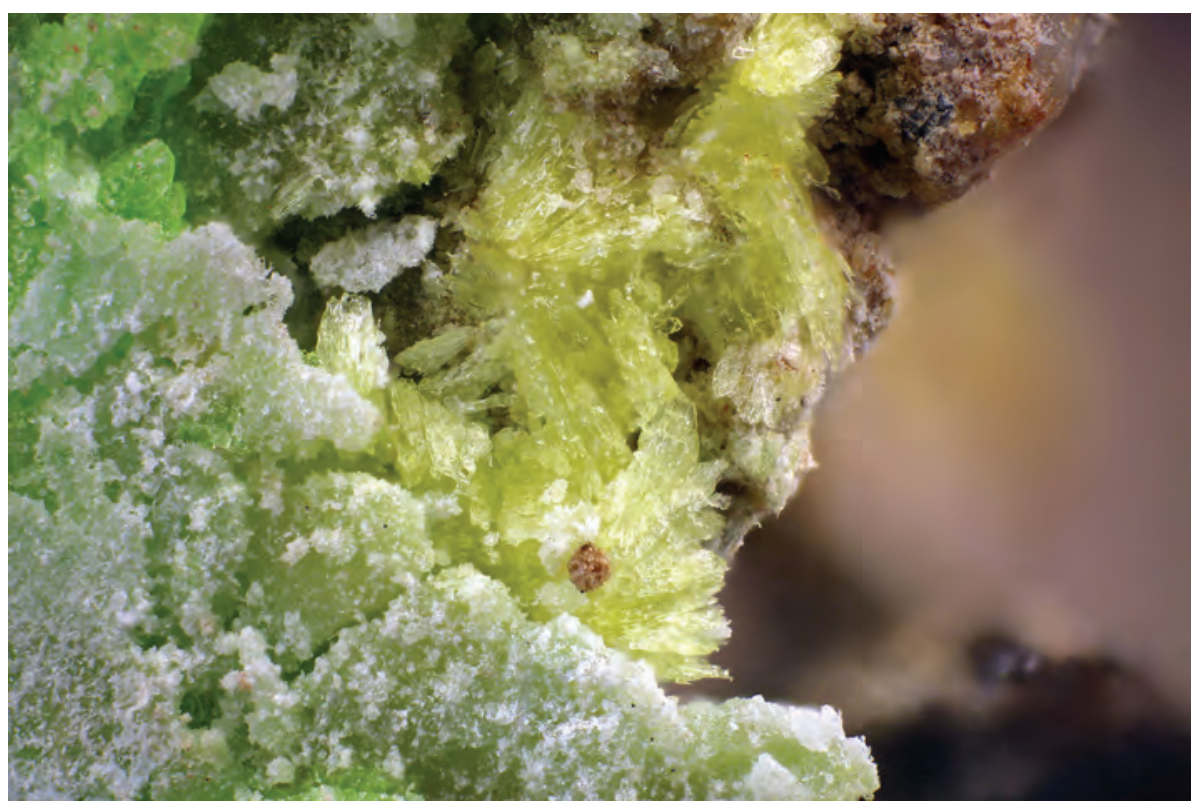

Tab. 1 Results of chemical analyses (in wt. \%) of svornostite

\begin{tabular}{lcccl}
\hline & Mean $(n=6)$ & Range & SD & Standard \\
\hline $\mathrm{K}_{2} \mathrm{O}$ & 7.93 & $7.34-8.71$ & 0.48 & Microcline \\
$\mathrm{MgO}$ & 3.11 & $2.75-3.93$ & 0.45 & Olivine \\
$\mathrm{CuO}$ & 0.79 & $0.00-2.40$ & 1.23 & $\mathrm{Cu}$ (metal.) \\
$\mathrm{SO}_{3}$ & 28.13 & $25.44-30.70$ & 2.51 & $\mathrm{BaSO}_{4}$ (synth.) \\
$\mathrm{UO}_{3}$ & 48.94 & $44.99-51.72$ & 2.74 & $\mathrm{UO}_{2}$ (synth.) \\
$\mathrm{H}_{2} \mathrm{O}$ & $12.53^{*}$ & & & \\
Total & 101.43 & & & \\
\hline
\end{tabular}

* calculated from the structure

$\mathrm{SD}$ - standard deviation

and $\{010\}$, and uneven fracture. The Mohs hardness is estimated at 2 . A density of $3.268 \mathrm{~g} / \mathrm{cm}^{3}$ was calculated based on the unit-cell dimensions from single-crystal $\mathrm{X}$-ray data and on the empirical formula from electron microprobe results. Svornostite shows strong yellowishgreen fluorescence under both long- and short-wave UV radiation. The mineral is optically biaxial positive, with $\alpha=1.548(2), \beta=1.556(3)$ and $\gamma=1.585(2)$ (measured at $590 \mathrm{~nm}$ ), birefringence of 0.037 and $2 V_{\text {calc. }}=56^{\circ}$. No dispersion or pleochroism was observed. The optical orientation is $Z=\mathbf{c}$. The Gladstone-Dale compatibility, $1-\left(\mathrm{K}_{\mathrm{p}} / \mathrm{K}_{\mathrm{c}}\right)$, is good $(0.039)$ for the empirical formula and the single-crystal unit-cell.

\section{Chemical composition}

The chemical composition of svornostite was determined using a CamScan4D scanning electron microscope (SEM) equipped with an Oxford Link ISIS energy-dispersive Xray spectrometer. An operating voltage of $20 \mathrm{kV}$ was used with a beam current of $500 \mathrm{pA}$ and a $1 \mu \mathrm{m}$ beam diameter. The EDS mode on the SEM was chosen for the analysis instead of the WDS mode on the electron microprobe (EMP) because svornostite was found to be less stable under the highvacuum and higher probe current. A special attention was paid to the overlap of the $U$ and $\mathrm{K}$ lines in the EDS spectrum, thus to the good resolution of the $\mathrm{K} K_{\alpha}$ and $\mathrm{U} M_{\alpha}$ analytical lines during measurement of $\mathrm{K}$; the $\mathrm{U}$ content was measured using the $\mathrm{U} L$ line. The content of molecular $\mathrm{H}_{2} \mathrm{O}$ was not deter-

Fig. 1 Bright-yellow prismatic crystals of svornostite in association with greenish geschieberite (IMA2014-006) and coatings of white gypsum on altered gangue from Jáchymov. Width of image is $2.5 \mathrm{~mm}$ (photo P. Škácha). 
mined directly, because of the paucity of pure material for thermal analysis. The $\mathrm{H}_{2} \mathrm{O}$ content was calculated from stoichiometry obtained from the structure model. Presence of $\mathrm{H}_{2} \mathrm{O}$ was independently proven by Raman spectroscopy.

The empirical formula of svornostite, calculated as the mean of 6 representative spot analyses (Tab. 1), is $\mathrm{K}_{1.94}\left(\mathrm{Mg}_{0.89} \mathrm{Cu}_{0.11}\right)_{\Sigma 1.00}\left(\mathrm{U}_{0.99} \mathrm{O}_{2}\right)_{2}\left(\mathrm{~S}_{1.01} \mathrm{O}_{4}\right)_{4}\left(\mathrm{H}_{2} \mathrm{O}\right)_{8}$ (based on $28 \mathrm{O} a p f u$ ). The simplified formula, $\mathrm{K}_{2} \mathrm{Mg}\left(\mathrm{UO}_{2}\right)_{2}\left(\mathrm{SO}_{4}\right)_{4}\left(\mathrm{H}_{2} \mathrm{O}\right)_{8}$, requires $\mathrm{K}_{2} \mathrm{O} 8.05, \mathrm{MgO} 3.43$, $\mathrm{UO}_{3} 48.89, \mathrm{SO}_{3} 27.32, \mathrm{H}_{2} \mathrm{O} 12.31$, total 100 wt. \%.

\section{Raman spectroscopy}

A Raman spectrum of svornostite (Fig. 2) was collected in the range $50-3500 \mathrm{~cm}^{-1}$ using a DXR dispersive Raman spectrometer (Thermo Scientific) mounted on a confocal Olympus microscope $(100 \times$ objective). The Raman signal was excited by a $532 \mathrm{~nm}$ diode-pumped solid-state laser and detected by a CCD detector. The experimental parameters were: $5 \mathrm{~s}$ exposure time, 32 exposures, 400 lines $/ \mathrm{mm}$ grating, $50 \mathrm{~mm}$ slit spectrograph aperture and
$2.5 \mathrm{~mW}$ laser power level. The instrument was set up by a software-controlled calibration procedure using multiple neon emission lines (wavelength calibration), multiple polystyrene Raman bands (laser frequency calibration) and standardized white-light sources (intensity calibration).

The general features of the vibration spectra of uranylsulfate minerals and their characteristics were thoroughly reviewed by Čejka (1999). Recently, Raman spectra of several structurally related uranyl sulfates, among others bobcookite, $\mathrm{NaAl}\left(\mathrm{UO}_{2}\right)_{2}\left(\mathrm{SO}_{4}\right)_{4} \cdot 18 \mathrm{H}_{2} \mathrm{O}$ (IMA2013-030, Kampf et al. 2014) were investigated. We based the assignment and interpretation of the Raman spectrum of svornostite on the similarities with the spectra of bobcookite and oppenheimerite, and also on the well-resolved Raman spectrum of natural zippeite (Plášil et al. 2010).

Interestingly, svornostite spectrum contains wellresolved $\mathrm{O}-\mathrm{H}$ stretching vibrations, which is uncommon in case of unpolarized Raman spectroscopy. However, similarly well-resolved bands in the $\mathrm{O}-\mathrm{H}$ stretching region were observed in the spectrum of bluelizardite (Plášil et al. 2014b) or plášilite (Kampf et al. 2015a). Raman bands at 3622,3545 and $3496 \mathrm{~cm}^{-1}$ in the svornostite

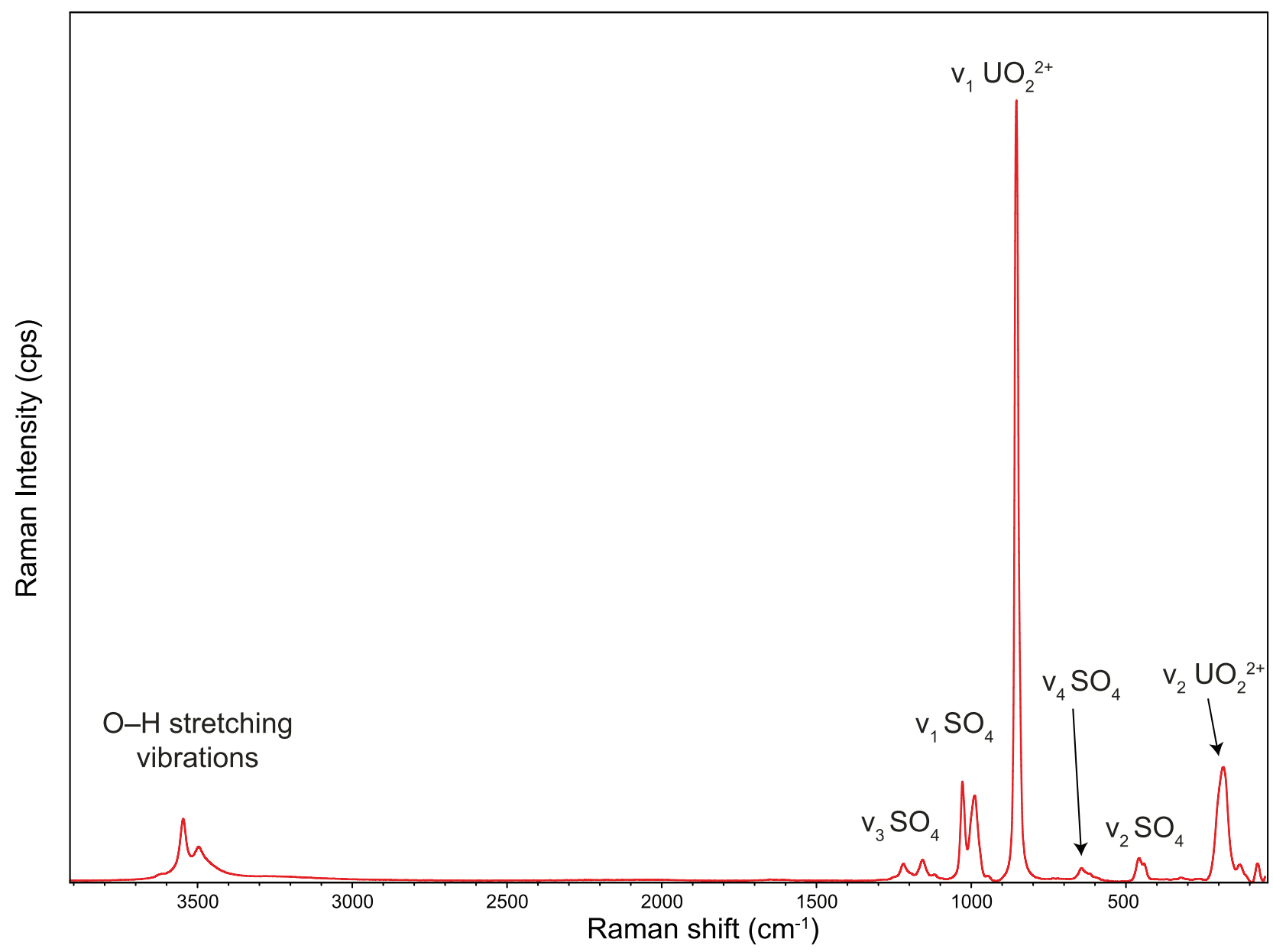

Fig. 2 The Raman spectrum of svornostite. 
spectrum are attributed to $v \mathrm{O}-\mathrm{H}$ stretching vibrations of symmetrically distinct $\mathrm{H}_{2} \mathrm{O}$ molecules. The $\mathrm{O}-\mathrm{H} \cdots \mathrm{O}$ hydrogen bond lengths, inferred using the empirical relation given by Libowitzky (1999), vary in the range $\sim 3.2$ to $2.9 \AA$. These values are consistent with the $\mathrm{O} \cdots \mathrm{O}$ interatomic distances of the corresponding hydrogen- bonded $\mathrm{H}_{2} \mathrm{O}$ molecules inferred from the X-ray structure study. Bands at 1220, 1200, 1155 and $1110 \mathrm{~cm}^{-1}$ are attributed to triply degenerate $v_{3}\left(\mathrm{SO}_{4}\right)^{2-}$ antisymmetric stretching vibrations and those at 1028 and $989 \mathrm{~cm}^{-1}$ to $v_{1}\left(\mathrm{SO}_{4}\right)^{2-}$ symmetric stretching vibrations. A very weak band at 951 and a very strong one at $854 \mathrm{~cm}^{-1}$ are assigned to $v_{3}$ $\left(\mathrm{UO}_{2}\right)^{2+}$ antisymmetric and $v_{1}\left(\mathrm{UO}_{2}\right)^{2+}$ symmetric stretching vibrations, respectively. The approximate $\mathrm{U}-\mathrm{O}$ bond length inferred from the respective wavenumbers of the $\left(\mathrm{UO}_{2}\right)^{2+}$ vibrations after Bartlett and Cooney (1989) is $\sim 1.76 \AA$, which is in line with the bond lengths obtained from the structure refinement. A very weak band at $725 \mathrm{~cm}^{-1}$ is probably connected with libration of $\mathrm{H}_{2} \mathrm{O}$ molecules. Bands at 643 and $610 \mathrm{~cm}^{-1}$ are attributed to triply degenerate $v_{4}(\delta)\left(\mathrm{SO}_{4}\right)^{2-}$ bending vibrations, and those at 458 and $438 \mathrm{~cm}^{-1}$ to $v_{2}(\delta)\left(\mathrm{SO}_{4}\right)^{2-}$ bending vibrations. A weak band at $322 \mathrm{~cm}^{-1}$ can be assigned to the $v$ (U-O $\mathrm{O}_{\text {ligand }}$ ) vibration. A weak band at $268 \mathrm{~cm}^{-1}$ together with a shoulder at $207 \mathrm{~cm}^{-1}$ may probably be assigned to split, doubly degenerate $v_{2}(\delta)\left(\mathrm{UO}_{2}\right)^{2+}$ bending vibrations. However, the shoulder may be related to a set of lattice vibrations at 186, 132 and $75 \mathrm{~cm}^{-1}$. From the number of observed bands of $\left(\mathrm{SO}_{4}\right)^{2-}$ vibrations it may be inferred that structurally (symmetrically) distinct $\left(\mathrm{SO}_{4}\right)^{2-}$ groups are present in the structure of svornostite.

\section{X-ray crystallography and structure determination}

\subsection{Powder diffraction}

X-ray powder diffraction data (Tab. 2) were obtained from a hand-picked sample using a PANalytical Empy-

Tab. 2 Powder diffraction data for svornostite

\begin{tabular}{|c|c|c|c|c|c|c|c|c|c|c|c|c|c|}
\hline$I_{\text {rel }}$ & $d_{\mathrm{obs}}$ & $d_{\text {calc }}$ & $I_{\text {calc }}$ & $h$ & $k$ & $l$ & $I_{\text {rel }}$ & $d_{\mathrm{obs}}$ & $d_{\text {calc }}$ & $I_{\text {calc }}$ & $h$ & $k$ & $l$ \\
\hline 50 & 8.279 & 8.275 & 48 & 0 & 1 & 0 & 11 & 2.546 & 2.545 & 13 & 2 & 2 & 3 \\
\hline 2 & 6.901 & 6.947 & $<1$ & 1 & 1 & 0 & 5 & 2.533 & 2.533 & 5 & 2 & 3 & 0 \\
\hline 32 & 6.661 & 6.660 & 27 & 0 & 1 & 1 & 5 & 2.476 & 2.475 & 5 & 0 & 3 & 2 \\
\hline 100 & 6.398 & 6.393 & 100 & 2 & 0 & 0 & 15 & 2.470 & 2.470 & 11 & 2 & 3 & 1 \\
\hline 20 & 5.613 & 5.611 & 18 & 0 & 0 & 2 & 10 & 2.467 & 2.468 & 10 & 4 & 2 & 1 \\
\hline 55 & 5.060 & 5.059 & 52 & 2 & 1 & 0 & 6 & 2.454 & 2.454 & 6 & 2 & 1 & 4 \\
\hline 40 & 4.645 & 4.644 & 40 & 0 & 1 & 2 & 1 & 2.431 & 2.430 & $<1$ & 1 & 3 & 2 \\
\hline 38 & 4.610 & 4.612 & 37 & 2 & 1 & 1 & 1 & 2.385 & 2.387 & 1 & 5 & 1 & 1 \\
\hline 1 & 4.359 & 4.365 & 2 & 1 & 1 & 2 & 3 & 2.331 & 2.332 & 6 & 4 & 1 & 3 \\
\hline 23 & 4.217 & 4.217 & 24 & 2 & 0 & 2 & 3 & 2.308 & 2.308 & 3 & 2 & 3 & 2 \\
\hline 5 & 4.137 & 4.137 & 3 & 0 & 2 & 0 & 3 & 2.236 & 2.240 & 1 & 5 & 1 & 2 \\
\hline 2 & 3.983 & 3.985 & 2 & 3 & 0 & 1 & 6 & 2.220 & 2.220 & 7 & 0 & 3 & 3 \\
\hline 34 & 3.881 & 3.882 & 35 & 0 & 2 & 1 & 3 & 2.206 & 2.211 & 1 & 1 & 0 & 5 \\
\hline 29 & 3.757 & 3.757 & 30 & 2 & 1 & 2 & 5 & 2.109 & 2.109 & 7 & 4 & 0 & 4 \\
\hline 7 & 3.588 & 3.590 & 2 & 3 & 1 & 1 & 17 & 2.097 & 2.095 & 16 & 4 & 2 & 3 \\
\hline 24 & 3.409 & 3.409 & 27 & 0 & 1 & 3 & 1 & 2.090 & 2.088 & 1 & 4 & 3 & 0 \\
\hline 6 & 3.330 & 3.330 & 5 & 0 & 2 & 2 & 3 & 2.068 & 2.069 & 3 & 0 & 4 & 0 \\
\hline 44 & 3.318 & 3.318 & 49 & 2 & 2 & 1 & 3 & 2.063 & 2.064 & 6 & 6 & 1 & 0 \\
\hline 6 & 3.218 & 3.222 & 1 & 1 & 2 & 2 & 11 & 2.053 & 2.053 & 13 & 4 & 3 & 1 \\
\hline 22 & 3.197 & 3.197 & 27 & 4 & 0 & 0 & 2 & 2.045 & 2.043 & 6 & 4 & 1 & 4 \\
\hline 44 & 3.009 & 3.008 & 50 & 2 & 1 & 3 & 4 & 2.030 & 2.030 & 6 & 6 & 1 & 1 \\
\hline 4 & 2.986 & 2.982 & 7 & 4 & 1 & 0 & 2 & 1.9938 & 1.9923 & 6 & 6 & 0 & 2 \\
\hline 14 & 2.955 & 2.953 & 15 & 2 & 2 & 2 & 4 & 1.9736 & 1.9728 & 6 & 0 & 2 & 5 \\
\hline 5 & 2.884 & 2.882 & 8 & 4 & 1 & 1 & 5 & 1.9678 & 1.9682 & 3 & 2 & 4 & 0 \\
\hline 6 & 2.800 & 2.806 & 8 & 0 & 0 & 4 & 2 & 1.9569 & 1.9572 & 3 & 4 & 3 & 2 \\
\hline 19 & 2.776 & 2.775 & 17 & 0 & 2 & 3 & 6 & 1.9408 & 1.9410 & 6 & 0 & 4 & 2 \\
\hline 4 & 2.758 & 2.758 & 1 & 0 & 3 & 0 & 6 & 1.9358 & 1.9369 & 5 & 6 & 1 & 2 \\
\hline 16 & 2.679 & 2.679 & 17 & 0 & 3 & 1 & 7 & 1.8861 & 1.8851 & 11 & 2 & 2 & 5 \\
\hline 10 & 2.658 & 2.657 & 10 & 0 & 1 & 4 & 6 & 1.8704 & 1.8703 & 6 & 0 & 0 & 6 \\
\hline 5 & 2.634 & 2.633 & 10 & 4 & 1 & 2 & 6 & 1.8667 & 1.8681 & 9 & 6 & 2 & 1 \\
\hline 3 & 2.602 & 2.601 & 1 & 1 & 1 & 4 & 13 & 1.8574 & 1.8573 & 17 & 2 & 4 & 2 \\
\hline 6 & 2.570 & 2.569 & 8 & 2 & 0 & 4 & & & & & & & \\
\hline
\end{tabular}

$d$ values quoted in $\AA$ 
rean diffractometer equipped with a PIXcel $^{3 \mathrm{D}}$ detector using $\mathrm{Cu} K_{\alpha}$ radiation $(45 \mathrm{kV}, 40 \mathrm{~mA})$ and operating in Debye-Scherrer geometry provided by focusing Göbel mirror optics. Data were collected in the range $3-50^{\circ} 2 \theta$, with the step size of $0.01^{\circ}$ and counting time of 2 s per step, using an accumulation of 20 scans to improve the intensity statistics. Positions and intensities of diffractions were refined using a pseudo-Voigt shape function with the High-Score (PANalytical) program. Unit-cell parameters were refined by leastsquares with the Celref program (Laugier and Bochu 2003). The theoretical pattern, used for indexing the experimental dataset, was calculated from the structure data using PowderCell (Kraus and Nolze 1996). Refined unit-cell parameters of svornostite obtained from powder data are $a=12.787(3), b=8.275(2)$, $c=11.222(3) \AA$, with $V=1187.5(5)$ $\AA^{3}$ and $Z=2$.

\subsection{Single-crystal X-ray diffraction and structu- re solution}

A prismatic single crystal of svornostite, with dimensions $0.24 \times 0.07 \times 0.05 \mathrm{~mm}$, was selected under the microscope and examined using an Oxford Diffraction Gemini single-crystal diffractometer with an Atlas CCD detector using monochromatized $\mathrm{MoK}_{\alpha}$ radiation, with a fibre-optic Mo-Enhance collimator. The unit-cell dimensions were refined from 10483 reflections by least-squares with the CrysalisPro package (Agilent Technologies 2014). According to

Fig. 3 The crystal structure of svornostite viewed down c. Infinite uranyl sulfate chains (blue and yellow, respectively) run parallel to the viewing direction. Adjacent chains are linked by Mg-octahedra (orange), the $\mathrm{K}-\mathrm{O}$ bonds ( $\mathrm{K}$ atoms are violet) and a $\mathrm{H}$-bond network (not displayed); O atoms are red spheres. Unit-cell edges are outlined by the solid black line.

Tab. 3 Crystallographic data and refinement details for svornostite

\section{Crystal data}

Formula

Crystal system

Space group

Unit-cell parameters: $a, b, c[\AA]$

Unit-cell volume $\left[\AA^{3}\right]$

Z

Calculated density $\left[\mathrm{g} / \mathrm{cm}^{3}\right]$

Crystal size [mm]

\section{Data collection}

Diffractometer

Temperature $[\mathrm{K}]$

Radiation, wavelength $[\AA]$

$\theta$ range for data collection $\left[{ }^{\circ}\right]$

Limiting Miller indices

Axis, frame width $\left({ }^{\circ}\right)$, time per frame (s)

Total reflections collected

Unique reflections

Unique observed reflections, criterion

Absorption coefficient $\left[\mathrm{mm}^{-1}\right]$, type

$T_{\min } / T_{\max }$

$R_{\text {int }}$

$F_{000}$

\section{Structure refinement by Jana2006}

No. of ref. param., restraints, constraints $R, w R$ (obs)

$R, w R$ (all)

GOF obs/all

Weighting scheme, weights

Largest diff. peak and hole $\left(\mathrm{e}^{-} / \AA^{3}\right)$

Absolute structure parameter, Friedel pairs

Twin matrix

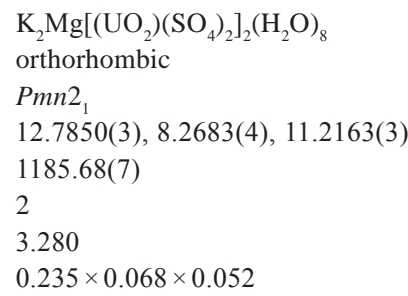

Oxford Diffraction Gemini with Atlas detector 300

$\mathrm{Mo} K_{\alpha}, 0.71073(50 \mathrm{kV}, 30 \mathrm{~mA})$

2.9029 .30

$h=-17 \rightarrow 16, k=-11 \rightarrow 11, l=-14 \rightarrow 14$

$\omega, 0.8,350$

19142

3108

$2745,[I>3 \sigma(I)]$

14.492; multi-scan

$0.574 / 1$

0.047

1044

Full-matrix least-squares on $F^{2}$

$179,1,0$

$0.0230,0.0567$

$0.0280,0.0587$

$1.38,1.34$

$\sigma, w=1 /\left(\sigma^{2}(I)+0.0004 I^{2}\right)$

$-0.98,1.40$

$0.018(9), 1410$

$\left(\begin{array}{ccc}-1 & 0 & 0 \\ 0 & -1 & 0 \\ 0 & 0 & -1\end{array}\right)$

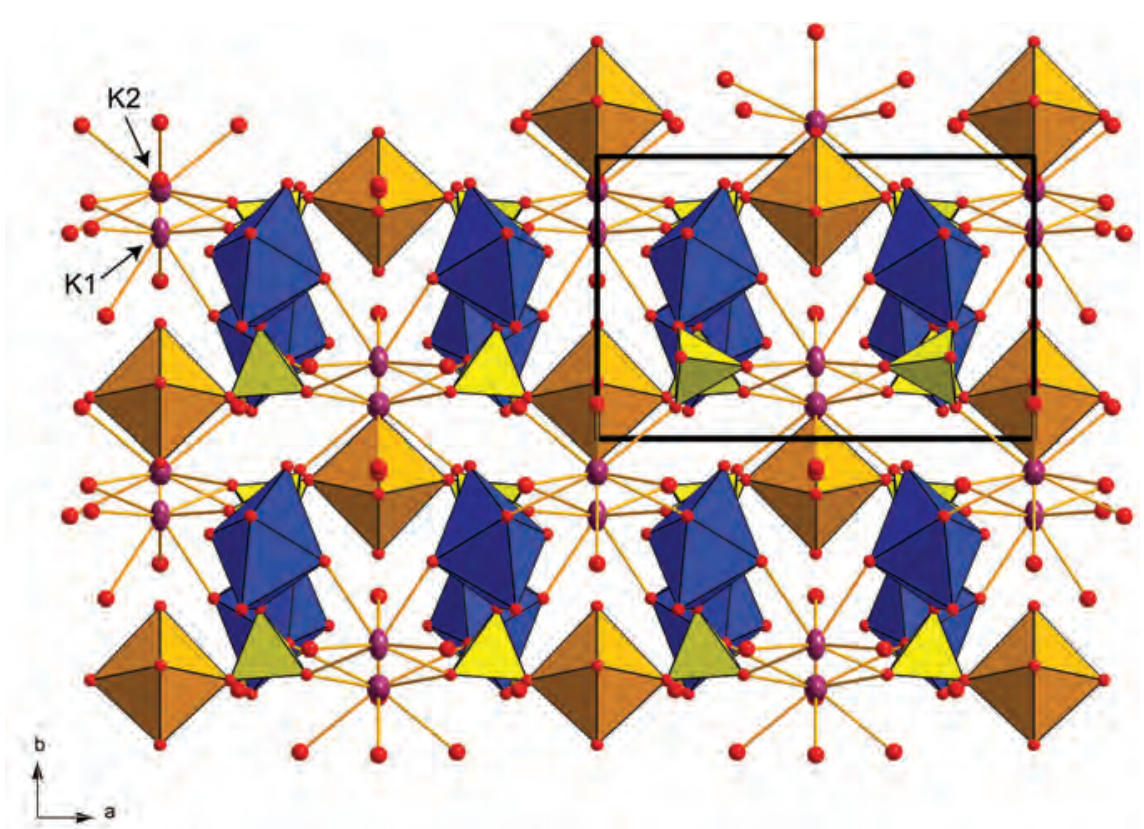




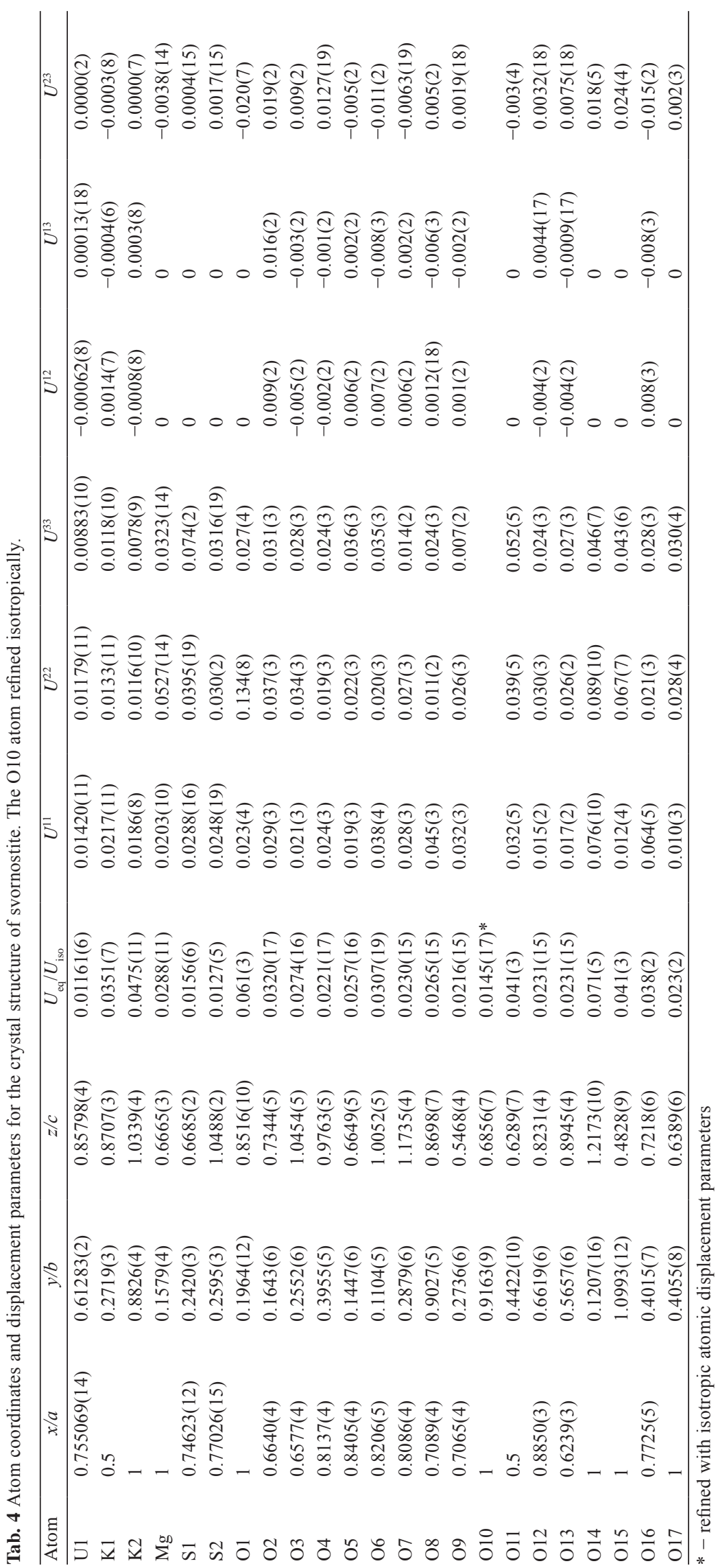

single-crystal X-ray data, svornostite is orthorhombic with $a=12.7850(3)$, $b=8.2683(4), c=11.2163(3) \AA$, $V=1185.68(7) \AA^{3}$ and $Z=2$. Of the 19142 collected reflections, 3108 were independent and 2745 were classified as observed based on the criterion $\left[I_{\text {obs }}>3 \sigma(I)\right]$. Data were corrected for Lorentz effect, polarization factor and background and an empirical (multi-scan) correction for absorption was applied to the dataset using the ABSPACK3 algorithm implemented in the RED routine of the CrysAlis software (Agilent Technologies 2014), leading to $R_{\text {int }}$ of 0.047 . Other details of the data collection are given in Tab. 3 .

The crystal structure of svornostite was solved by the charge-flipping algorithm implemented in the Superflip program (Palatinus and Chapuis 2007) and subsequently refined using the software Jana2006 (Petrríček et al. 2006, 2014) with the full-matrix least-squares refinement based on $F^{2}$. The reflection conditions and statistics indicated orthorhombic primitive cell and the non-centrosymmetric space group Pnm2 1 was confirmed by the refinement of the structure. Nearly all atoms with the unit-cell were found by the solution, some of the $\mathrm{O}$ atoms were localized by the difference Fourier syntheses. Nearly all atoms were refined using harmonic atomic-displacement parameters. Attempts to localize hydrogen atoms from the difference Fourier maps failed. The refinement converged smoothly with final indices of agreement $R=0.0230$ and $w R=0.0567$ for 2745 observed reflections with GOF $=1.34$ (Tab. 3 ). The atom coordinates and the displacement parameters are given in Tab. 4 and selected interatomic distances in Tab. 5. Bond-valences are shown in Tab. 6.

\subsection{Description of the crystal structure}

The structure of svornostite (Fig. 3) contains one $\mathrm{U}$, two $\mathrm{S}$, one $\mathrm{Mg}$, two $\mathrm{K}$ and eighteen $\mathrm{O}$ sites in the asymmetric unit. The $\mathrm{U}$ site, occupied by $\mathrm{U}^{6+}$, is coordinated by $7 \mathrm{O}$ atoms, two of which form the uranyl ion, $\mathrm{UO}_{2}^{2+}$, and five more form a squat pentagonal bipyramid. This shares 
four of the equatorial vertices with sulfate tetrahedra such that each tetrahedron is linked to two uranyl bipyramids to form an infinite chain (Fig. 4). The free, non-linking equatorial vertex of the uranyl bipyramid is occupied by an $\mathrm{H}_{2} \mathrm{O}$ molecule. The $\mathrm{Mg}$ site is coordinated octahedrally by six ligands including two $\mathrm{O}$ atoms and four $\mathrm{H}_{2} \mathrm{O}$ molecules. The $\mathrm{O}$ atoms of the $\mathrm{Mg}$ octahedra belong to $\mathrm{SO}_{4}$ tetrahedra of the chains. Therefore, Mg octahedra link adjacent chains (Fig. 3). Additional linkage is provided by the $\mathrm{K}-\mathrm{O}$ bonds, involving either $\mathrm{O}$ atoms of the $\mathrm{SO}_{4}$ groups or $\mathrm{O}_{\text {Uranyl }}$ atoms. Acceptors of the $\mathrm{H}$-bonds (Tab. 6) within the structural units are the $\mathrm{O} 12_{\text {Uranyl }}$ atom, which can accept two H-bonds, the $\mathrm{O} 3_{\text {Sulphur }}$ atom, which can accept one $\mathrm{H}$-bond, $\mathrm{O} 6_{\text {Sulphur }}$, which can accept two $\mathrm{H}$-bonds and $\mathrm{O} 13_{\text {Uranyl }}$ and $\mathrm{O} 12_{\text {Uranyl }}$ atoms, which also can accept one $\mathrm{H}$-bond. The structural formula of svornostite obtained from the refinement is $\mathrm{K}_{2} \mathrm{Mg}\left[\left(\mathrm{UO}_{2}\right)\right.$ $\left.\left(\mathrm{SO}_{4}\right)_{2}\left(\mathrm{H}_{2} \mathrm{O}\right)\right]_{2}\left(\mathrm{H}_{2} \mathrm{O}\right)_{6}$. The EDS showed possibly $\mathrm{Cu}^{2+}$ to be entering most probably the octahedrally coordinated Mg site; however, this theory was not substantiated by the structure refinement.

\section{Discussion - structure topology and structure relations}

The infinite uranyl sulfate chains present in the structure of svornostite are a well-known structural feature found in other uranyl sulfates, e.g., in bobcookite (IMA2014030), $\mathrm{NaAl}\left(\mathrm{UO}_{2}\right)_{2}\left(\mathrm{SO}_{4}\right)_{4} \cdot 18 \mathrm{H}_{2} \mathrm{O}$ (Kampf et al. 2014), or the synthetic compounds $\mathrm{K}_{2}\left[\left(\mathrm{UO}_{2}\right)\left(\mathrm{SO}_{4}\right)_{2}\left(\mathrm{H}_{2} \mathrm{O}\right)\right]\left(\mathrm{H}_{2} \mathrm{O}\right)$ (Ling et al. 2010) and $\mathrm{Mn}\left(\mathrm{UO}_{2}\right)\left(\mathrm{SO}_{4}\right)_{2}\left(\mathrm{H}_{2} \mathrm{O}\right)_{5}$ (Tabachenko et al. 1979).

It should be noticed here that svornostite is structurally very similar to the group of synthetic compounds prepared by Serezhkin and Serezhkina $(1977,1978,1982)$ and by Tabachenko et al. (1979). These synthetic uranyl sulfate hydrates $\mathrm{M}^{2+}\left[\left(\mathrm{UO}_{2}\right)\left(\mathrm{SO}_{4}\right)_{2}\right] \cdot x \mathrm{H}_{2} \mathrm{O}$ have layered structures $(x \sim 11)$ or chain structures $(x \sim 5)$; in all of them the $\left[\left(\mathrm{UO}_{2}\right)\left(\mathrm{SO}_{4}\right)_{2}\left(\mathrm{H}_{2} \mathrm{O}\right)\right]^{2-}$ units are present. The structural relations among these units were studied in detail especially in case of the $\mathrm{Mg}^{2+}$-containing compounds. Uranium coordination polyhedra are pentagonal $\left[\left(\mathrm{UO}_{2}\right) \mathrm{O}_{4}\left(\mathrm{H}_{2} \mathrm{O}\right)\right]$ bipyramids. Each uranyl ion coordinates four monodentate sulfate groups and one water molecule as in svornostite. Layer structures $\left(x \sim 11 \mathrm{H}_{2} \mathrm{O}\right)$, where the $\left[\mathrm{M}^{2+}\left(\mathrm{H}_{2} \mathrm{O}\right)_{6}\right]^{2+}$ octahedra and remaining water molecules are

Fig. 4 Infinite uranyl sulfate chain found in the structure of svornostite; O8 marks the site occupied by $\mathrm{H}_{2} \mathrm{O}$.
Tab. 5 Selected interatomic distances $(\AA)$ and angles $\left({ }^{\circ}\right)$ in the structure of svornostite

\begin{tabular}{|c|c|c|c|c|c|}
\hline $\mathrm{U}-\mathrm{O} 12$ & $1.754(4)$ & $\mathrm{S} 1-\mathrm{O} 2$ & $1.436(6)$ & $\mathrm{S} 2-\mathrm{O} 3$ & $1.440(5)$ \\
\hline $\mathrm{U}-\mathrm{O} 13$ & $1.770(4)$ & $\mathrm{S} 1-\mathrm{O} 5$ & $1.449(5)$ & $\mathrm{S} 2-\mathrm{O} 4$ & $1.495(5)$ \\
\hline $\mathrm{U}-\mathrm{O} 4$ & $2.356(5)$ & $\mathrm{S} 1-\mathrm{O} 9$ & $1.480(5)$ & $\mathrm{S} 2-\mathrm{O} 6$ & $1.474(5)$ \\
\hline $\mathrm{U}-\mathrm{O} 7^{\mathrm{i}}$ & $2.370(5)$ & $\mathrm{S} 1-\mathrm{O} 16$ & $1.486(6)$ & $\mathrm{S} 2-\mathrm{O} 7$ & $1.501(5)$ \\
\hline U-O8 & $2.472(4)$ & $<\mathrm{S} 1-\mathrm{O}>$ & 1.463 & $<\mathrm{S} 2-\mathrm{O}>$ & 1.478 \\
\hline $\mathrm{U}-\mathrm{O} 9^{\mathrm{ii}}$ & $2.368(5)$ & & & & \\
\hline U-O16 & $2.331(6)$ & & & & \\
\hline$<\mathrm{U}-\mathrm{O}_{U r}>$ & 1.762 & & & & \\
\hline$<\mathrm{U}-\mathrm{O}_{\mathrm{eq}}>$ & 2.379 & & & & \\
\hline $\mathrm{K} 1-\mathrm{O} 2$ & $2.743(6)$ & $\mathrm{K} 2-\mathrm{O} 1^{\mathrm{v}}$ & $3.304(11)$ & $\mathrm{Mg}-\mathrm{O} 1$ & $2.100(11)$ \\
\hline $\mathrm{K} 1-\mathrm{O} 2^{\mathrm{iii}}$ & $2.743(6)$ & $\mathrm{K} 2-\mathrm{O}^{\mathrm{i}}$ & $3.099(6)$ & $\mathrm{Mg}-\mathrm{O} 5$ & $2.042(5)$ \\
\hline $\mathrm{K} 1-\mathrm{O} 3$ & $2.815(5)$ & $\mathrm{K} 2-\mathrm{O}^{\mathrm{v}}$ & $2.985(6)$ & $\mathrm{Mg}-\mathrm{O} 5^{\mathrm{iv}}$ & $2.042(5)$ \\
\hline $\mathrm{K} 1-\mathrm{O} 3^{\mathrm{iii}}$ & $2.815(5)$ & $\mathrm{K} 2-\mathrm{O}^{\mathrm{i}}$ & $2.943(5)$ & $\mathrm{Mg}-\mathrm{O} 10^{\text {ix }}$ & $2.009(8)$ \\
\hline $\mathrm{K} 1-\mathrm{O} 11$ & $3.056(9)$ & $\mathrm{K} 2-\mathrm{O} 11^{\mathrm{i}}$ & $2.889(9)$ & $\mathrm{Mg}-\mathrm{O} 15^{\text {ix }}$ & $2.117(10)$ \\
\hline $\mathrm{K} 1-\mathrm{O} 13$ & $2.912(5)$ & $\mathrm{K} 2-\mathrm{O} 12$ & $3.329(5)$ & $\mathrm{Mg}-\mathrm{O} 17$ & $2.070(7)$ \\
\hline $\mathrm{K} 1-\mathrm{O} 13^{\mathrm{iii}}$ & $2.912(5)$ & $\mathrm{K} 2-\mathrm{O} 14^{\mathrm{ix}}$ & $2.847(13)$ & $<\mathrm{Mg}-\mathrm{O}>$ & 2.063 \\
\hline $\mathrm{K} 1-\mathrm{O} 15^{\mathrm{ii}}$ & $3.317(10)$ & $<\mathrm{K} 2-\mathrm{O}>$ & 3.057 & & \\
\hline$<\mathrm{K} 1-\mathrm{O}>$ & 2.914 & & & & \\
\hline O1-O4 & $3.216(9)$ & $\mathrm{O} 4-\mathrm{O}^{\mathrm{ii}}$ & $2.860(6)$ & $\mathrm{O} 8-\mathrm{O}^{\mathrm{ii}}$ & $2.690(8)$ \\
\hline $\mathrm{O} 1-\mathrm{O} 4^{\mathrm{iv}}$ & $3.216(9)$ & $\mathrm{O} 4-\mathrm{O} 11^{\mathrm{ii}}$ & $3.225(7)$ & $\mathrm{O} 8-\mathrm{O} 12$ & $3.050(7)$ \\
\hline $\mathrm{O} 1-\mathrm{O} 5$ & $2.954(9)$ & $\mathrm{O} 4-\mathrm{O} 12$ & $2.939(6)$ & O8-O13 & $3.004(6)$ \\
\hline $\mathrm{O} 1-\mathrm{O} 5^{\mathrm{iv}}$ & $2.954(9)$ & $\mathrm{O} 4-\mathrm{O} 13$ & $2.952(7)$ & $\mathrm{O} 8-\mathrm{O} 14^{\mathrm{i}}$ & $3.178(9)$ \\
\hline $\mathrm{O} 1-\mathrm{O} 6$ & $2.955(9)$ & $\mathrm{O} 4-\mathrm{O} 16$ & $2.903(8)$ & O8-O15 viii & $2.957(7)$ \\
\hline $\mathrm{O} 1-\mathrm{O}^{\mathrm{iv}}$ & $2.955(9)$ & $\mathrm{O} 4-\mathrm{O} 18^{\mathrm{v}}$ & $2.851(3)$ & O9-O11 & $3.125(6)$ \\
\hline $\mathrm{O} 1-\mathrm{O} 10^{\mathrm{v}}$ & $2.971(13)$ & $\mathrm{O} 5-\mathrm{O} 8^{\mathrm{i}}$ & $3.392(9)$ & O9-O12 & $2.819(6)$ \\
\hline O1-O17 & $2.946(13)$ & O5-O9 & $2.413(7)$ & O9-O13 & $3.064(6)$ \\
\hline O2-O5 & $2.392(7)$ & $\mathrm{O} 5-\mathrm{O} 10^{\mathrm{v}}$ & $2.789(7)$ & O9-O16 & $2.384(8)$ \\
\hline $\mathrm{O} 2-\mathrm{O}^{\mathrm{v}}$ & $2.704(7)$ & $\mathrm{O} 5-\mathrm{O} 15^{\mathrm{v}}$ & $2.910(9)$ & O10-O12 & 2.994(8) \\
\hline O2-O9 & $2.354(7)$ & O5-O16 & $2.381(8)$ & $\mathrm{O} 10-\mathrm{O} 12^{\mathrm{iv}}$ & $2.994(8)$ \\
\hline $\mathrm{O} 2-\mathrm{O} 11$ & $3.329(8)$ & O5-O17 & $2.982(7)$ & O10-O15 & $2.732(12)$ \\
\hline $\mathrm{O} 2-\mathrm{O} 14^{\mathrm{vi}}$ & $3.160(11)$ & O6-O7 & $2.397(7)$ & $\mathrm{O} 12-\mathrm{O} 12^{\mathrm{iv}}$ & $2.941(6)$ \\
\hline $\mathrm{O} 2-\mathrm{O} 16$ & $2.406(8)$ & O6-O8v & $2.701(8)$ & O12-O16 & $2.828(8)$ \\
\hline $\mathrm{O} 3-\mathrm{O} 4$ & $2.434(7)$ & O6-O9 $9^{\text {vii }}$ & $3.227(6)$ & O12-O17 & $3.305(7)$ \\
\hline 6 & 2 & 14 & 3.3 & $\begin{array}{l}\text { O13- } \\
\text { O13 }\end{array}$ & $3.167(6)$ \\
\hline $\mathrm{O} 3-\mathrm{O} 7$ & $2.421(7)$ & $\mathrm{O} 7-\mathrm{O}^{\mathrm{ii}}$ & 2.7 & $\begin{array}{l}\text { O13- } \\
\text { O15 }\end{array}$ & $3.341(10)$ \\
\hline $\mathrm{O} 3-\mathrm{O} 10^{\mathrm{ii}}$ & $2.924(7)$ & $\mathrm{O} 7-\mathrm{O} 11^{\mathrm{ii}}$ & $3.349(7)$ & O13-O16 & $3.034(8)$ \\
\hline $\mathrm{O} 3-\mathrm{O} 12^{\mathrm{ii}}$ & $3.235(7)$ & $\mathrm{O} 7-\mathrm{O} 12^{\mathrm{ii}}$ & $3.019(6)$ & $\mathrm{O} 13-\mathrm{O} 17^{\mathrm{ii}}$ & $3.175(7)$ \\
\hline O3-O13 & $3.106(7)$ & $\mathrm{O} 7-\mathrm{O} 13^{\mathrm{ii}}$ & $2.890(6)$ & $\mathrm{O} 14-015^{\mathrm{x}}$ & $2.984(15)$ \\
\hline O4-O6 & $2.381(6)$ & O7-O14 & $2.853(8)$ & $\mathrm{O} 15-\mathrm{O} 17^{\mathrm{ix}}$ & $3.078(12)$ \\
\hline O4-O7 & $2.385(7)$ & $\mathrm{O} 7-\mathrm{O} 16^{\mathrm{ii}}$ & $2.822(8)$ & $014-015^{x}$ & $2.984(15)$ \\
\hline
\end{tabular}

Symmetry codes: (i) $-x+3 / 2,-y+1, z-1 / 2$; (ii) $-x+3 / 2,-y+1, z+1 / 2$; (iii) $-x+1, y, z$; (iv) $-x+2, y, z$; (v) $x, y-1, z$; (vi) $-x+3 / 2,-y, z-1 / 2$; (vii) $-x+3 / 2,-y, z+1 / 2$; (viii) $-x+3 / 2,-y+2, z+1 / 2$; (ix) $x, y+1, z$; (x) $x, y-1, z+1$.

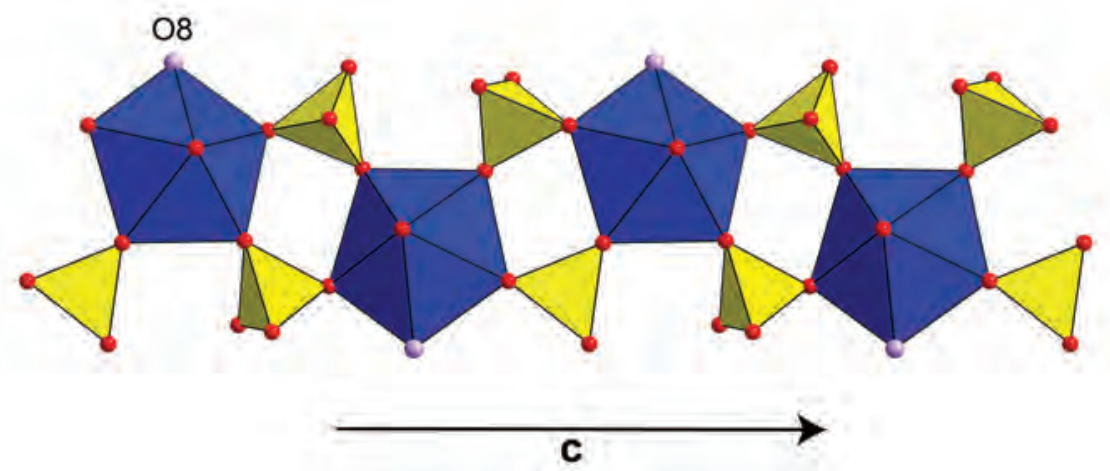


Tab. 6 The bond-valence analysis for svornostite

\begin{tabular}{|c|c|c|c|c|c|c|c|c|c|}
\hline & $\mathrm{U}$ & S1 & $\mathrm{S} 2$ & K1 & K2 & $\mathrm{Mg}$ & $\sum \mathrm{BV}^{\mathrm{A}}$ & Species & $+\mathrm{H}^{+}$ \\
\hline O1 & & & & & 0.04 & 0.33 & 0.37 & $\mathrm{H}_{2} \mathrm{O}$ & +1.6 \\
\hline $\mathrm{O} 2$ & & 1.66 & & $0.19 \times 2 \downarrow$ & $0.07 \times 2 \downarrow$ & & 1.92 & $\mathrm{O}^{2}$ & \\
\hline O3 & & & 1.640 & $0.16 \times 2 \downarrow$ & & & 1.80 & $\mathrm{O}$ & +0.2 \\
\hline $\mathrm{O} 4$ & 0.54 & & 1.42 & & & & 1.96 & $\mathrm{O}$ & \\
\hline O5 & & 1.60 & & & & $0.39 \times 2 \downarrow$ & 1.99 & $\mathrm{O}$ & \\
\hline O6 & & & 1.50 & & $0.10 \times 2 \downarrow$ & & 1.60 & $\mathrm{O}$ & +0.4 \\
\hline O7 & 0.53 & & 1.37 & & & & 1.90 & $\mathrm{O}$ & \\
\hline O8 & 0.43 & & & & & & 0.43 & $\mathrm{H}_{2} \mathrm{O}$ & +1.6 \\
\hline O9 & 0.53 & 1.48 & & & $0.11 \times 2 \downarrow$ & & 2.12 & $\mathrm{O}^{2}$ & \\
\hline O10 & & & & & & 0.43 & 0.43 & $\mathrm{H}_{2} \mathrm{O}$ & +1.6 \\
\hline O11 & & & & 0.08 & 0.13 & & 0.21 & $\mathrm{H}_{2} \mathrm{O}$ & +1.8 \\
\hline $\mathrm{O} 12$ & 1.77 & & & & $0.04 \times 2 \downarrow$ & & 1.81 & $\mathrm{O}^{2}$ & +0.2 \\
\hline O13 & 1.71 & & & $0.12 \times 2 \downarrow$ & & & 1.83 & $\mathrm{O}$ & +0.2 \\
\hline O14 & & & & & 0.14 & & 0.14 & $\mathrm{H}_{2} \mathrm{O}$ & +1.8 \\
\hline O15 & & & & 0.04 & & 0.32 & 0.36 & $\mathrm{H}_{2} \mathrm{O}$ & +1.6 \\
\hline O16 & 0.57 & 1.45 & & & & & 2.02 & $\mathrm{O}^{2}$ & \\
\hline O17 & & & & & & 0.36 & 0.36 & $\mathrm{H}_{2} \mathrm{O}$ & +1.6 \\
\hline$\sum \mathrm{BV}^{\mathrm{C}}$ & 6.08 & 6.19 & 5.93 & 1.06 & 0.95 & 2.22 & & & \\
\hline
\end{tabular}

All values are in valence units $(v u) ; \times 2 \downarrow-$ multiplicity; $\sum \mathrm{BV}^{\mathrm{C}}-$ sum of the bond-valences of cations; $\sum \mathrm{BV}^{\mathrm{A}}$ - sum of the bond-valences of anions; $+\mathrm{H}^{+}$- inferred contribution of the $\mathrm{H}$-bonds; an average $\mathrm{H}$-bond strength is of $0.2 v u, \mathrm{O}_{\text {donor }}-\mathrm{H}$ is equivalent to $\sim 0.8 v u$ (Schindler and Hawthorne 2008). Values of +0.2 and +0.4 correspond thus to the acceptance of one or two H-bonds. A value of +1.6 is characteristic of the transformer $\mathrm{H}_{2} \mathrm{O}$ group $2 * 0.8 v u$. A value of +1.8 corresponds to the non-transformer $\mathrm{H}_{2} \mathrm{O}$ group $=\Delta+2 * 0.8+0.2 v u$. Bond valence parameters are taken from Burns et al. (1997), for $\mathrm{U}^{6+}-\mathrm{O}$, and from Brown and Altermatt (1985) for $\mathrm{K}^{+}-\mathrm{O}, \mathrm{S}^{6+}-\mathrm{O}$ and $\mathrm{Mg}^{2+}-\mathrm{O}$.

located between the layers, transform in chain structures $\left(x \sim 5 \mathrm{H}_{2} \mathrm{O}\right)$ during the partial irreversible dehydration. During such dehydration process, all $\mathrm{H}_{2} \mathrm{O}$ molecules non-coordinated to metal cations and the two $\mathrm{H}_{2} \mathrm{O}$ molecules in trans positions of $\left[\mathrm{M}^{2+}\left(\mathrm{H}_{2} \mathrm{O}\right)_{6}\right]^{2+}$ octahedra are released from the structure. In structures of pentahydrates, the coordination polyhedra involving $\mathrm{M}^{2+}$ consist of four $\mathrm{H}_{2} \mathrm{O}$ and two terminal $\mathrm{O}$ atoms adhering to $\mathrm{SO}_{4}$ groups, as in case of svornostite. Chemical formulae of both type of compounds are therefore $\left[\mathrm{Mg}\left(\mathrm{H}_{2} \mathrm{O}\right)_{6}\right]\left[\left(\mathrm{UO}_{2}\right)\right.$ $\left.\left(\mathrm{SO}_{4}\right)_{2}\left(\mathrm{H}_{2} \mathrm{O}\right)\right] \cdot 4 \mathrm{H}_{2} \mathrm{O}$ and $\left[\mathrm{Mg}\left(\mathrm{H}_{2} \mathrm{O}\right)_{4}\left[\left(\mathrm{UO}_{2}\right)\left(\mathrm{SO}_{4}\right)_{2}\left(\mathrm{H}_{2} \mathrm{O}\right)\right]\right.$, respectively.

Acknowledgements. We appreciate kind cooperation of Pavel Škácha, who provided photomicrographs of svornostite. Professor V. N. Serezhkin (University of Samara) is highly acknowledged for e-prints of several papers of his. The current text benefited from the constructive comments of Nicolas Meisser and Stuart Mills. František Laufek is thanked for editorial handling of the manuscript. This research was financially supported by the post-doctoral grant of the GAČR no. 13-31276P to JP and by the long-term project DKRVO 2015-02 of the Ministry of Culture of the Czech Republic (National Museum 00023272) to J. C.
Electronic supplementary material. Supplementary crystallographic data for this paper are available online at the Journal web site (http://dx.doi.org/10.3190/jgeosci.192).

\section{References}

Agilent Technologies (2014) CrysAlis CCD and CrysAlis RED. Oxford Diffraction Ltd, Yarnton, Oxfordshire, UK

BARTLETt JR, CoOney RP (1989) On the determination of uranium-oxygen bond lengths in dioxouranium(VI) compounds by Raman spectroscopy. J Mol Struct 193: 295-300

Brown ID, Altermatt D (1985) Bond-valence parameters obtained from a systematic analysis of the inorganic crystal structure database. Acta Cryst B41: 244-248

Brugger J, Meisser N, Burns PC (2003) Contribution to the mineralogy of acid drainage of uranium minerals: marecottite and the zippeite-group. Amer Miner 88: 676-685

Burns PC, Ewing RC, Hawthorne, FC (1997) The crystal chemistry of hexavalent uranium: polyhedron geometries, bond-valence parameters, and polymerization of polyhedra. Canad Mineral 35: 1551-1570

ČEJKA J (1999) Infrared spectroscopy and thermal analysis of the uranyl minerals. In: Burns PC, FINCH RJ (eds) Uranium: Mineralogy, Geochemistry and the Environment. Mineralogical Society of America and Geochemical Society Reviews in Mineralogy and Geochemistry 38, Washington, pp 521-622

Fernandes HM, Veiga LHS, Franklin MR, Prado VCS, TADDEI JF (1995) Environmental impact assessment of uranium mining and milling facilities; a study case at the Poços de Caldas uranium mining and milling site, Brazil. In: Allan RJ, Salomons W (eds), Heavy Metal Aspects of Mining Pollution and Its Remediation. J Geochem Explor 52: 161-173

Finch RJ, Murakami T (1999) Systematics and paragenesis of uranium minerals. In: BuRns PC, FINCH RJ (eds) Uranium: Mineralogy, Geochemistry and the Environment. Mineralogical Society of America and Geochemical Society Reviews in Mineralogy and Geochemistry 38, Washington, pp 91-179

Hloušek J, Plášil J, Sejkora J, ŠKácha P (2014) News and new minerals from Jáchymov, Czech Republic (2003-2014). Bull mineral-petrolog odd Nár Muz (Praha) 22: $155-181$

Johnson DB (2003) Chemical and microbiological characteristics of mineral spoils and drainage waters at abandoned coal and metal mines. Water Air Soil Pollut: Focus 3: 47- 66

Johnson DB, Hallberg KB (2005) Acid mine drainage remediation options: a review. Sci Total Environ 338: $3-14$ 
KampF AR, PláŠIl J, Kasatkin AV, Marty J (2014) Bobcookite, IMA2014-030. CNMNC Newsletter No. 21, August 2014, page 802. Mineral Mag 78: 797-804

KampF AR, Kasatkin AV, ČEJKa J, Marty J (2015a) Plášilite, $\mathrm{Na}\left(\mathrm{UO}_{2}\right)\left(\mathrm{SO}_{4}\right)(\mathrm{OH}) \cdot 2 \mathrm{H}_{2} \mathrm{O}$, a new uranyl sulfate mineral from the Blue Lizard mine, San Juan County, Utah, USA. J Geosci 60: 1-10

Kraus W, Nolze G (1996) POWDER CELL - a program for the representation and manipulation of crystal structures and calculation of the resulting X-ray powder patterns. J Appl Cryst 29: 301-303

Krivovichev SV, PlášIl J (2013) Mineralogy and Crystallography of Uranium. In: BuRns PC, Sigmon GE (eds) Uranium: From Cradle to Grave. Mineralogical Association of Canada Short Courses 43: pp 15-119

Laugier J, Bochu B (2003) CELREF: Unit Cell Refinement Program from Powder Diffraction Diagram. Laboratoires des Matériaux et du Génie Physique, Ecole Nationale Supérieure de Physique de Grenoble (INPG), Grenoble, France. Accessed on September 15, 2014, at http://pcb4122.univ-lemans.fr/du-sdpd/nexus/ccp14/ web/tutorial/lmgp/

LiBowitzky E (1999) Correlation of O-H stretching frequencies and $\mathrm{O}-\mathrm{H}$... O hydrogen bond lengths in minerals. Monatsh Chem 130: 1047-1059

Ling J, Sigmon GE, Ward M, Roback N, Burns PC (2010) Syntheses, structures, and IR spectroscopic characterization of new uranyl sulfate/selenate 1D-chain, 2D-sheet and 3D framework. Z Kristallogr 225: 230-239

Ondruš P, Veselovský F, HloušEK J, SkÁla R, VAVŘín I, FrÝdA J, ČEJKA J, GaBAŠOVÁ A (1997) Secondary minerals of the Jáchymov (Joachimsthal) ore district. J Czech Geol Soc 42: 3-76

Ondruš P, Veselovský F, Gabašová A, Drábek M, Dobeš P, Malý K, Hloušek J, Sejkora J (2003) Ore-forming processes and mineral parageneses of the Jáchymov ore district. J Czech Geol Soc 48: 157-192

Palatinus L, Chapuis G (2007) Superflip - a computer program for the solution of crystal structures by charge flipping in arbitrary dimensions. J Appl Cryst 40: 451-456

Petříček V, Dušek M, Palatinus L (2006) Jana2006. The crystallographic computing system. Institute of Physics,
Prague, Czech Republic. Accessed on March 24, 2015 , at http://jana.fzu.cz

Petříček V, Dušek M., Palatinus L (2014) Crystallographic computing system Jana 2006: general features. Z Kristallogr 229: 345-352

PlášIL J (2014) Oxidation-hydration weathering of uraninite: the current state-of-knowledge. J Geosci 59: 99-114

Plášil J, Buixaderas E, Čejka J, SeJKora J, JehličKa J, NovÁK M (2010) Raman spectroscopic study of the uranyl sulphate mineral zippeite: low wavenumber and U-O stretching regions. Anal Bioanal Chem 397:2703-2715

Plášil J, Hloušek J, Veselovský F, Fejfarová K, Dušek M, ŠKoda R, Novák M, ČEJKa J, SEJKora J, Ondruš P (2012) Adolfpateraite, $\mathrm{K}\left(\mathrm{UO}_{2}\right)\left(\mathrm{SO}_{4}\right)(\mathrm{OH})\left(\mathrm{H}_{2} \mathrm{O}\right)$, a new uranyl sulphate mineral from Jáchymov, Czech Republic. Amer Miner 97: 447-454

Plášil J, Hloušek J, Kasatkin AV, ŠKoda R, Novák M, ČEJKA J (2014a) Geschieberite, IMA 2014-006. CNMNC Newsletter No. 20, June 2014, page 555. Mineral Mag 78: 549-558

Plášil J, KampF AR, Kasatkin AV, Marty J (2014b) Bluelizardite, $\mathrm{Na}_{7}\left(\mathrm{UO}_{2}\right)\left(\mathrm{SO}_{4}\right)_{4} \mathrm{Cl}\left(\mathrm{H}_{2} \mathrm{O}\right)_{2}$, a new uranyl sulfate mineral from the Blue Lizard mine, San Juan County, Utah, USA. J Geosci 59: 145-158

Schindler M, Hawthorne FC (2008) The stereochemistry and chemical composition of interstitial complexes in uranyl-oxysalt minerals. Canad Mineral 46: 467-501

Serezhrin VN, Serezhrina LB (1977) New double uranyl sulfates. Radiokhim 19: 807-810 (in Russian)

SEREZHKIN VN, SEREZHKINA LB (1978) X-ray investigation of double uranyl sulfates $\mathrm{MUO}_{2}\left(\mathrm{SO}_{4}\right)_{2} \cdot 5 \mathrm{H}_{2} \mathrm{O}$. Zhur Neorgan Khim 23: $752-755$ (in Russian)

Serezhrin VN, Serezhrina LB (1982) On some properties of disulfatouranylate hydrates of divalent metals. Zhur Neorgan Khim 27: 424-430 (in Russian)

Tabachenko VV, Serezhrin VI, Serezhrina LB, Kovba LM (1979) Crystal structure of manganese sulfatouranylate $\mathrm{MnUO}_{2}\left(\mathrm{SO}_{4}\right)_{2}\left(\mathrm{H}_{2} \mathrm{O}\right)_{5}$. Khoordinats Khim 5: 1563-1568 (in Russian)

TVRDÝ J, PlÁšIL J (2010) Jáchymov - Reiche Erzlagerstätte und Radonbad im böhmischen Westerzgebirge. Aufschluss 61: 277-292 